\title{
Herschel S. Horowitz: the Dentist-Scientist
}

\section{Amid I. Ismail, BDS, MPH, DrPH}

Neither fire nor wind, birth nor death can erase our good deeds.

$$
\text { -Buddha }
$$

Dr. Herschel S. Horowitz was a premiere dentist-scientist who had a career filled with major achievements in promoting oral health, critical thinking, and most importantly, scientific honesty and humility. Hersh was born in Detroit, attended college at Wayne State University, and then enrolled in the School of Dentistry at the University of Michigan. After a two-year service in the army dental corps in Japan, Hersh returned to Detroit and worked for a short while as a dentist with the Detroit Department of Health. Hersh decided to study dental public health in the late 1950s and received a USPHS traineeship. After graduating with a master's in public health, he was hired by the Division of Dental Resources and then the Division of Dental Health, Disease Control Branch. Hersh found his métier when he was assigned to the position of field investigator under the direction of $D r$. Frank Law. After one year in that position, Dr. Law retired, and Hersh became the chief of the Division of Dental Public Health Resources Research and Development Section. According to Hersh he spent the following 25 years earning a salary for work that he loved to do (1). The rest of Hersh's journey will be covered by the other speakers. The purpose of this paper is to present some unique snapshots of Hersh's contributions using excerpts from his writings.

They say that life is a highway and its milestones are the years, and now and then there's a tollgate where you buy your way with tears.

$$
\text { -Joyce Kilmer }
$$

As a scientist, Hersh was a pioneer in the fields of clinical trials, fluoride research, and prevention of oral conditions. I cannot cover Hersh's entire scientific legacy in one presentation or paper. Reading his papers provides great practical lessons in scientific writing. He wrote with passion and candor, traits that are rare today. He had high moral commitment to his field and the communities he served (2):

Researchers are members of their communities. As community members, they have a responsibility to communicate risks to health, promote methods of maintaining health, help make policies for the community, educate all citizens of the community, and serve as expert witnesses where necessary. Scientific misconduct is incompatible with these responsibilities.

\section{The Dental Public Health Researcher}

Hersh used his talents in thinking, analysis, and writing to excel in the field of dental epidemiology and public health. Hersh admitted that he did not have the manual dexterity to become a successful dentist (1); however, he managed to become a great oral health specialist with many significant contributions to dentistry (1):

In essence ... I was able to make a silk purse out of a sow's ear. Although I have chosen a basic profession for which I was ill suited ... I ... found a niche within the profession-public health dentistry-which provided me a wonderful life in many ways.

\section{The Clinical Trialist}

Hersh believed that he was born during the halcyon days of clinical research: "just at the right time-neither 20 years too soon nor 20 years too late to participate, design, and conduct clinical trials on the effectiveness of caries preventive agents and regi- mens" (3). Hersh's mission was to find ways to help reduce the burden of dental caries in the United States (3):

During dental surveys, in which I participated as an examiner in the 1960 s, many children who presented themselves for examination had teeth that were riddled with untreated caries, frequently with unsightly black craters in anterior teeth. Dental care was a luxury.

Hersh started his dental public health career in the early 1960 s and found his niche in clinical preventive studies. He learned in a very short time from Dr. Frank Law "lessons that served him well for the next 37 years" of his career (2). Hersh led a team of dental public health researchers and plowed a research path that focused on finding methods to deliver fluoride to prevent dental caries.

Looking back at the successes achieved in reducing (but not eradicating) the burden of dental caries in US children, Hersh cautioned us that (3)

We must take lessons from history and not let budget cuts for caries research, a failure to maintain or implement known-to-be-effective preventive methods, a deteriorating public health infrastructure, and unrelieved poverty permit a recurrence of the plague of dental caries.

Hersh did not agree with the elimination of the National Caries Program at the National Institute of Dental Research in the mid-1980s-and, indeed, he was right.

Hersh's legacy in clinical research transcends the topic of fluoride, for which he had made many significant contributions. Hersh developed and wrote with colleagues the first guidelines for conducting clinical trials to test preventive agents; he conducted the first clinical trials on pit and fissure 
sealants; and throughout his writings, editorials, and rebuttals Hersh contributed significantly to the science of clinical research in dentistry (4-6).

\section{The Questioner}

Hersh's presence among the audience at a symposium or a workshop was always exciting because most moderators or members of the audience knew that Hersh would start a discussion and ask piercing, focused questions.

\section{A moderator at a symposium is supposed to keep a few questions handy to spark discussion. But when I was moderating and saw Hersh in the audience I knew that wouldn't be necessary! He loved a good argument in the strict sense of that word (i.e., a reasoned ex- change of views) ... Hersh knew that truth only advances when suppositions are held up to the light and given a good shake. $\mathrm{He}$ was one of the best at shaking sup- positions. \\ -Brian A. Burt (personal commu- nication, Dec 11, 2003)}

While his questions may have created shivers in the nerves of many speakers, Hersh was always warm and friendly, never arrogant or condescending.

At a personal level, Hersh was warm and wonderfully free of ego. I like to remember him as an entertaining dinner companion with his easy conversation on any topic. The wine always tasted better when Hersh was at the table... (In May 2004, I attended a symposium on clinical research at NIDCR. I really felt that Hersh was in attendance and I remembered his presence at the Natcher Building on the NIH campus at previous symposia.)

-Brian A. Burt (personal communication, Dec 11, 2003)

\section{The Writer}

Hersh was a prolific writer. $\mathrm{He}$ wrote 165 journal articles and 30 book chapters and monographs. His first article was on the "value of intraoral cytological testing for the early detection of oral cancer" (7). The study aimed to test the reliability and correlation validity of exfoliative cytology in detecting oral cancer. The study also attempted to "stimulate dentists" to engage in the detection of oral cancer. The study did not achieve its goal of collecting 2,000 smears. Instead, 600 smears were collected, 150 biopsies were performed, and 19 malignancies were detected. As a dentist-scientist, Hersh described his experiences and made several recommendations to improve the methods used in the study (7):

1. Forms should be simple and easy to understand.

2. Simplify the data collection forms.

3. Pathologists should be informed of how to complete the forms.

4. A system to keep dentists' supplies distributed.

5. Communicate progress with the participating dentists.

6. Attempt to get as many biopsies as possible.

7. Well-planned instructional sessions with all participants.

8. Use films and video to inform participants

In a paper written in 2003, Hersh displayed his candor when he wrote an editorial debating the Centers for Disease Control and Prevention (CDC) guidelines for fluoride use (8). Hersh and $I$ attended a meeting that was hastily organized to bring a number of experts who did not participate in the discussions that produced a working paper describing the proposed CDC guidelines. Hersh, as usual, had many comments and objections that he eloquently presented during the two days of the workshop. When the revised guidelines were later released, Hersh asked that his name be removed from the list of reviewers because some of his concerns were not addressed. However, when he reviewed the final release of the CDC guidelines, Hersh concluded that "the final report was improved to the point where, had I seen it, I may not have asked to have my name removed from the list of reviewers" (8).

Hersh felt it was his duty to say what he ought to say rather than what people thought he should say. When one day Hersh, at the urging of his secretary, was discarding folders that had not been used for some time, he noticed a letter he had written six years before to the editor of the Journal of the American Dental Association debating some of the papers presented at an ADA-sponsored symposium on "Attitudinal and Behavioral Research in Dentistry" (9). Hersh decided to write an editorial in the Journal of Public Health Dentistry on this topic. He stressed that the important outcome of behavioral change studies should be the incidence of dental diseases and not only the adoption of a new behavior per se (9):
We must know a lot more, how- ever, about motivating or chang- ing people or about instructing people in proper methods if we are going to improve their oral health.
Hersh, we will miss your writing style and sharp mind.

\section{The Critical Thinker}

I will not cover in this paper Hersh's voluminous writings on fluorides and caries prevention. I knew Hersh as an open-minded, critical, and dynamic thinker. In the 1980s he recognized the importance of fluoride in remineralization of initial or precarious lesions and fluoride's potential antimicrobial effect on plaque bacteria (10):

Until about 10 years ago, most dental experts thought that fluorides worked principally by increasing the resistance of enamel to acids produced in dental plaque by bacteria. More recent research clearly shows that other actions of fluoride, such as remineralization of initial or precarious lesions and a host of antimicrobial effects, are also important.

Hersh envisioned a day when (11) ... more will probably be learned about the best way to formulate and deliver dietary fluoride supplements. Also, it shall be learned whether it is better to formulate large tablets that stimulate salivary secretions to carry fluoride to all tooth surfaces or small tablets designed to dissolve slowly in a buccal recess to encourage prolonged contact of fluoride with the teeth.

Unfortunately, the cancellation of the 
National Caries Program halted such a vision from being realized.

There is no doubt that Hersh had the force of mind and the skill of writing to turn ideas into powerful tools that can influence the readers.

If there is one overriding characteristic of Hersh's works, it is that they appeal forcibly to the mind. His positions are always plainly set forth and rationally defended. In addition, Hersh was a strong believer in publishing negative results no matter how persuasive the existing evidence.

-James Beck (12)

\section{August 2003}

I had an urging to see Hersh just a week before he died, so I traveled to Bethesda on a beautiful sunny Saturday in early August 2003. Hersh saw me with a smile on his face and I felt relaxed seeing him. He insisted that we go to lunch with Alice, and while I drove my rental car he directed me toward downtown Bethesda. While Hersh was fragile and could not eat, he was curious about research, dental public health, and contemporary political issues. He and Alice also discussed which current movies were worth watching. After I left them that afternoon, I knew the days were precious few for Hersh; my heart was filled with sorrow and awe. In the evening, I decided to go see a movie Hersh had recommended. I stood in a long line to buy a ticket for "Winged Migration," a movie in which the actors were birds of different species, and the story was about their journey from one corner of earth to another in search of a more hospitable climate. While I watched the movie and listened to the music, I thought of my journey as an immigrant and of Hersh's life journey where, like some of the few silent human actors in that movie, he had shown the utmost respect and understanding for a young immigrant in the early 1980 s. Hersh is unique individual, for he is one of the few people whom I have met in my entire life with whom I did not feel classified prior to speaking and where no mental shackles were placed on me or on what I can achieve.

In conclusion, Hersh has left us with a rich legacy as a human being and dentist-scientist. He was a role model, gentleman, thoughtful individual, and a man who was open to people regardless of their color, race, ethnicity, religion, or gender. For all of his family, friends, and colleagues, the loss of Hersh has been hard to accept. For me, knowing Hersh will remain an honor, a privilege, and a highlight of $\mathrm{my}$ life-that is how I choose to deal with his passing. He is my role model. I am glad that in our short venture on earth, we met and knew each other.

And in the end it's not the years in your life that count. It's the life in your years.

-Abraham Lincoln

\section{References}

1. Horowitz HS. Remarks by Herschel S. Horowitz upon receiving the $1994 \mathrm{John}$ W. Knutson Distinguished Service Award in Dental Public Health. J Public Health Dent 1995;55:101-4.

2. Horowitz HS. Ethical issues in research (guest editorial). J Dent Res 1990;69:1345.

3. Horowitz HS. The halcyon days of clinical field studies of dental caries prevention, 1960-1980. J Dent Res 1998;77:13803.

4. Horowitz HS. Report of the American Dental Association's conference on clinical testing of cariostatic agents. J Public Health Dent 1969;29:49-52.

5. Horowitz HS. Clinical trials of preventives for dental caries. J Public Health Dent 1972;32:229-33.

6. Horowitz HS, Baume LJ, Backer Dirks O, Davies GN, Slack GL, eds. Principal requirements for controlled clinical trials of caries preventive agents and procedures. Int Dent J 1973;23:506-16.

7. Jordan WA, Horowitz HS. The Minnesota study of the applicability and value of intra-oral cytological testing for the early detection of oral cancer. NorthWest Dent 1963;42:326-9.

8. Horowitz HS. The 2001 CDC recommendations for using fluoride to prevent and control dental caries in the United States. J Public Health Dent 2003;63:3-8.

9. Horowitz HS. Can we measure the impact of communication information in terms of reduced incidence of dental disease? J Public Health Dent 1978:38:131-5.

10. Horowitz HS. Promotion of oral health and prevention of dental caries. J Public Health Dent 1981;41:92-5. (Reprinted by request in J Am Dent Assoc 1981;103:1413.)

11. Horowitz HS. The future of self-applied fluorides. J Public Health Dent 1981;41: 255-9.

12. Beck JD. American Association of Public Health Dentistry 1987 Distinguished Service Award: Herschel S. Horowitz. J Public Health Dent 1988;48:296-7. 